\title{
CHANGES IN TOTAL PCB CONTENT IN SELECTED FISH PRODUCTS DURING HOT- AND COLD SMOKING
}

\author{
Agata WITCZAK, Władysław CIERESZKO
}

\author{
Division of Toxicology, Agricultural University of Szczecin, Poland
}

\begin{abstract}
Witczak A., Ciereszko W. 2006. Changes in total PCB content in selected fish products during hot- and cold smoking. Acta Ichthyol. Piscat. 36 (1): 11-16.
\end{abstract}

\begin{abstract}
Background. Stability and high bioaccumulation coefficients of polychlorinated biphenyls (PCB) in aqueous organisms may constitute a health hazard for their consumers (it is really the potential toxicity of PCBs that determine their hazard - not stability). As the fish are mostly eaten in the form of processed products, the influence of technological processes and different methods of cooking on changes in the levels of toxic compounds in final products is of great importance and may be helpful for appropriate processing. Since smoked fish products are in great demand in Poland, the goal of this study was to determine changes in total PCB content in herring fillets during hot smoking and in hot and cold smoked mackerel fillets.

Materials and Methods. Herring fillets were hot smoked under industrial conditions, whereas mackerel fillets were cold- and hot smoked. Analyses were carried out using a capillary gas chromatograph coupled with a mass spectrometer GC-MS (HP 6890/5973) with a HP-5 column.

Results. The hot smoking process affected the loss of total PCB content in mackerel and herring fillets, with its highest value in the first hour of partial drying. The main factor determining the changes in the content of these compounds in wet matter and lipids was their escape in co-distillation with water vapour. The increase of their content, in the final stage of hot smoking and during the whole cold smoking process, was caused by contamination of fish fillets with polychlorinated biphenyls present in the curing smoke.

Conclusions. From the toxicological point of view the process of hot smoking, is much healthier for people because it causes the reduction of total PCB content in final smoked products. Cold smoked mackerel is much more popular on the Polish market for its stronger taste and aromatic smell. However, lengthy exposure to smoke in low temperature increased the total PCB content in cold smoked fish. The consumption of these products should be limited based on these results.
\end{abstract}

Keywords: PCB, hot smoking, cold smoking, mackerel, herring, fish

\section{INTRODUCTION}

Polychlorinated biphenyls belong to a group of synthetic chlorine-containing compounds. They are a mixture of congeners built of biphenyl rings, saturated by different number of chlorine atoms, ranging from 1 to 10 . These compounds are characterised by low vapour pressure and co-distil easily with water vapour. Due to their good heat conduction and dielectric properties, they were widely used in many industrial applications, mainly in electrical engineering. As a result of many years' production and broad application, they are present in all elements of natural environment and in foods of vegetable- and animal origin (Hansen 1987, Falandysz et al. 2002).

Due to exceptional stability and concerns for its toxicity, $\mathrm{PCB}$ production was discontinued or their application was limited to closed cycles in many countries (Booker 2001). The PCBs, as lipophilic compounds, are characterised by high bioaccumulation coefficients in living organisms, and consequently in food items, which is the main source of their assimilation for most populations (Falandysz 1986, Anonymous 1999).

Considering the potentially high content of these compounds in seafood, their consumption may constitute a threat for the health of consumers. Thus, an important issue is to understand the effect of manufacturing processes and culinary procedures on concentration changes of PCBs.

Since smoked fish products are in great demand in Poland, the goal of this study was to determine changes in total PCB content in herring fillets during hot smoking and in hot and cold smoked mackerel fillets. 


\section{MATERIALS AND METHODS}

The study material consisted of mackerel- and herring block fillets (= angel fillet or butterfly filet; a double fillet joined together along the back) from the fish caught in the Norwegian Sea in autumn 2001. After storing them at $-18^{\circ} \mathrm{C}$, the fillets were smoked. Supplementary raw materials were salt and a mixture of spicy condiment. Alder sawdust was used for smoke generation. The smoking was carried out under industrial conditions in a smoking chamber of the Atmos type (Kurko 1963), equipped with temperature- and humidity automatic control and forced-circulation warm-air heating system. The smoke generator was located outside the chamber. Prior to hot smoking, the mackerel and herring fillets were brined in $15 \% \mathrm{NaCl}$ solutions for $3 \mathrm{~min}$, whereas the mackerel fillets for cold smoking were brined $(15 \% \mathrm{NaCl})$ with spicy condiment (laurel leaves, allspice, paprika, and mustard) for $3 \mathrm{~h}$. In order to determine changes occurring in PCB levels during the brining and smoking, 5 block fillets were split longitudinally into two full nape fillets (single fillets which included belly flap and rib bones) (later referred to as fillets), half of which constituted control samples and the other were brined and smoked.

For the hot smoking process, 5 brined block fillets were randomly sampled and split into two full nape fillets, for smoking under assumed time intervals $(0.5 ; 1.0 ; 1.5$; 2.0 ; and $2.5 \mathrm{~h}$ ). During the first hour of smoking, the fillets were partially dried at $40^{\circ} \mathrm{C}$, whereupon the smoke was supplied to the smoking chamber and the temperature was raised to $80^{\circ} \mathrm{C}$. The process of hot smoking lasted for $2.5 \mathrm{~h}$. In addition, $28 \times 7 \mathrm{~cm}$ filtration paper strips imbibed in soybean oil (with an average surface area of single mackerel fillets of $196 \mathrm{~cm}^{2}$ ), were hang up on upper smoking bars. The smoking chamber charge was 2 smoking trolleys, $60 \mathrm{~kg}$ of raw product each, and the consumption of alder sawdust amounted to $20 \mathrm{~kg}$ per smoking cycle.

The samples of mackerel fillets for the cold smoking process were prepared similarly. Fish fillets were removed from the smoking chamber after 2,4 , and $6 \mathrm{~h}$ of smoking, while the final product was collected after $8 \mathrm{~h}$. The cold smoking was carried out at $27^{\circ} \mathrm{C}$. The smoking chamber charge was 2 smoking trolleys, with $80 \mathrm{~kg}$ of fish each, and the consumption of sawdust was $40 \mathrm{~kg}$ per smoking cycle.

To determine weight losses, the fillets were weighed before- and after the brining, as well as after successive smoking stages. For all samples, dry matter and lipid contents were determined. To determine which PCB congeners were present in the curing smoke, destructive wood distillation of alder sawdust was conducted under laboratory conditions. To determine recovery of analyzed PCB compounds, all samples were fortified with a known amount of surrogate Pesticides Surrogate Spike Mix (SUPELCO, USA), which was a solution of 2 compounds dissolved in acetone: decachlorobiphenyl and 2,4,5,6tetrachloro-m-xylen. This was aimed at determining the recovery of total $\mathrm{PCB}$, which amounted to $71 \%-88 \%$. "Chlorobiphenyls in mackerel oil" No. 350 (Promochem
$\mathrm{GmbH}$ ) was used as a reference material. In the analysis, a standard solution of 7 indicator congeners dissolved in isooctane (Promochem GmbH, D 46485 Wesel) was used. For determining the PCB total, a solution of 3 Aroclor standards (1242, 1254, 1260; N0132, N0135, and N0129, Promochem $\mathrm{GmbH}$ ) was used.

For analysing the content of polychlorobiphenyls, the fillets were homogenised after skinning. Samples of $30 \mathrm{~g}$ of the muscle tissue were weighed and used for analysis in three replicates. The samples were dried by rubbing them with roasted $\mathrm{Na}_{2} \mathrm{SO}_{4}$ (at $400^{\circ} \mathrm{C}$ for $4 \mathrm{~h}$ ) until uniform dry mass was obtained (according to Polish Standard PNEN 1528-2). The extraction of the target compounds and lipid content was carried out in two stages: $50 \mathrm{~mL}$ of acetone and n-hexane solution $(2.5: 1)$, followed by $50 \mathrm{~mL}$ $\mathrm{n}$-hexane and diethyl ether solution $(9: 1)$. After filtration, the combined extracts were concentrated in a rotary vacuum evaporator. The extract was transferred quantitatively into $10 \mathrm{~mL}$ weighed glass test-tubes, and evaporated under nitrogen atmosphere, and residues were desiccated at $60^{\circ} \mathrm{C}$ to a solid mass for determination of lipid content. The analysis for PCB compounds was continued by dissolving again the obtained lipid in n-hexane to $2 \mathrm{~mL}$. Then, the sample was purified with $6 \mathrm{~mL}$ fuming $\mathrm{H}_{2} \mathrm{SO}_{4}$ ( $7 \% \mathrm{SO}_{3}$ in concentrated $\mathrm{H}_{2} \mathrm{SO}_{4}$ ). After layer separation, the upper layer was rinsed three times with deionised water and dried with anhydrous $\mathrm{Na}_{2} \mathrm{SO}_{4}$. Next, the sample was concentrated in a rotary vacuum evaporator to 0.1 $\mathrm{mL}$, and transferred to a tight vial.

The sample prepared this way was analysed with the method of gas chromatography coupled with mass spectrometry GC-MS (HP 6890/5973). A HP-5 column with $5 \%$ phenyl methyl siloxane $(30 \mathrm{~m}$, ID $250 \mu \mathrm{m}$, film thickness $0.25 \mu \mathrm{m}$ ) column was used. The analyses were made under the following chromatograph conditions: pulsed, splitless injection $2 \mu \mathrm{L}$; carrier gas-helium; column through-flow- $1.0 \mathrm{~mL} \cdot \mathrm{min}^{-1}$; pressure $-83.43 \mathrm{kPa}(12.1$ psi); temperature programme of oven's column $-140^{\circ} \mathrm{C}$ (hold $0.5 \mathrm{~min}$ ), increase $5^{\circ} \mathrm{C} \cdot \min -1,200^{\circ} \mathrm{C}$ (hold $5 \mathrm{~min}$ ), increase $10^{\circ} \mathrm{C} \cdot \mathrm{min}^{-1}, 280^{\circ} \mathrm{C}$ (hold $10 \mathrm{~min}$ ), increase $30^{\circ} \mathrm{C}$ $\cdot \mathrm{min}^{-1}, 300^{\circ} \mathrm{C}$ (hold $1 \mathrm{~min}$ ).

Statistical processing of the results included analysis of variance with the aid of ANOVA tests (using STATISTICA 6.1 software package) and determination of appropriate coefficients of correlation and regression equations.

\section{RESULTS}

The average content of dry matter in the initial products was: $33.45 \% \pm 0.63 \%$ ( \pm standard deviation $s$ ) in herring fillets, $36.22 \% \pm 0.62 \%$ in hot smoked mackerel and $36.88 \% \pm 0.21 \%$ in cold smoked mackerel, and the lipid content was $14.42 \% \pm 0.21 \%, 18.93 \% \pm 0.99 \%$, and $18.74 \% \pm 0.21 \%$, respectively.

Mean total PCB content in herring fillets before the brining was $64.35 \pm 0.67 \mu \mathrm{g} \cdot \mathrm{kg}^{-1}$ of wet weight matter $(\mathrm{w} / \mathrm{w})$. In mackerel fillets assigned for hot smoking, mean PCB levels were $20.06 \pm 0.43 \mu \mathrm{g} \cdot \mathrm{kg}^{-1} \mathrm{w} / \mathrm{w}$, whereas in mackerel fillets for cold smoking mean PCB levels we- 
re18.22 $\pm 0.45 \mu \mathrm{g} \cdot \mathrm{kg}^{-1} \mathrm{w} / \mathrm{w}$. Lipid normalized data for PCBs was: $446.25 \pm 11.77 \mu \mathrm{g} \cdot \mathrm{kg}^{-1}$ in herring fillets, $105.97 \pm 2.47 \mu \mathrm{g} \cdot \mathrm{kg}^{-1}$ in mackerel fillets assigned for hot smoking, and $97.22 \pm 0.41 \mu \mathrm{g} \cdot \mathrm{kg}^{-1}$ in mackerel fillets assigned for cold smoking (Fig. 1a-c).

Both in the mackerel and the herring fillets, no significant $(P<0.05)$ changes of total PCB were detected in wet

a)

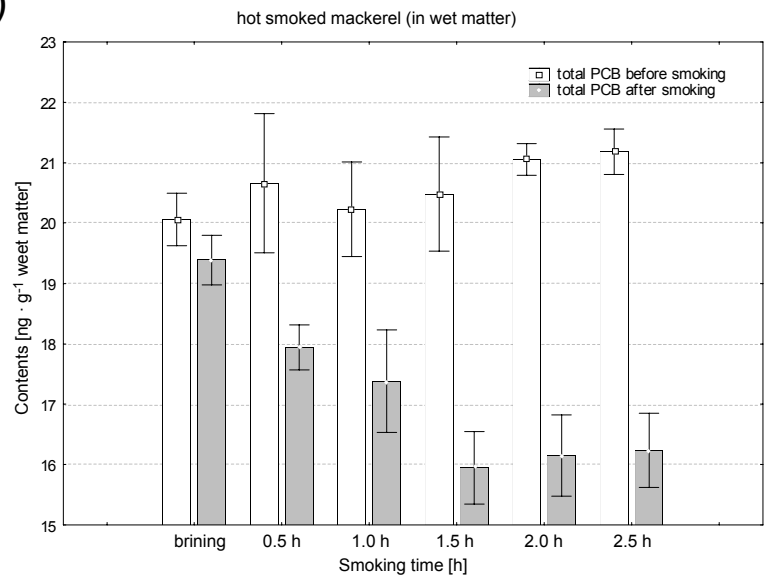

b)

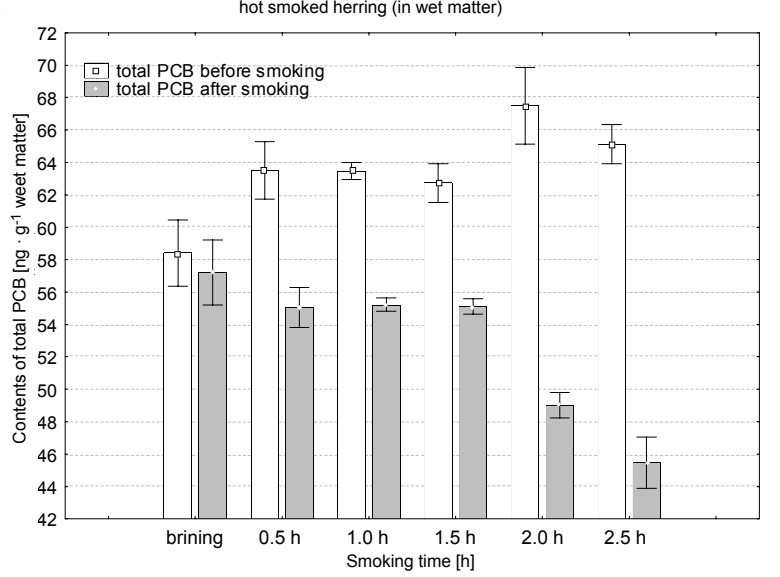

C)

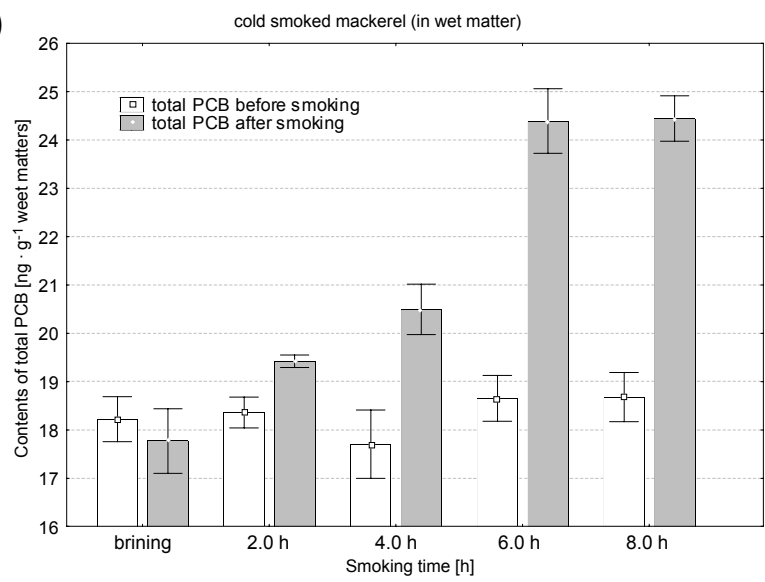

weight or lipid normalized samples during the brining (Fig. 1).

During the hot smoking of mackerel fillets, a drop in total PCB content in wet weight was found in the preliminary smoking by 14.09 percentage points. During the proper smoking (after a preliminary drying, with smoke), the losses ranged from 22.12 percentage points after $1.5 \mathrm{~h}$
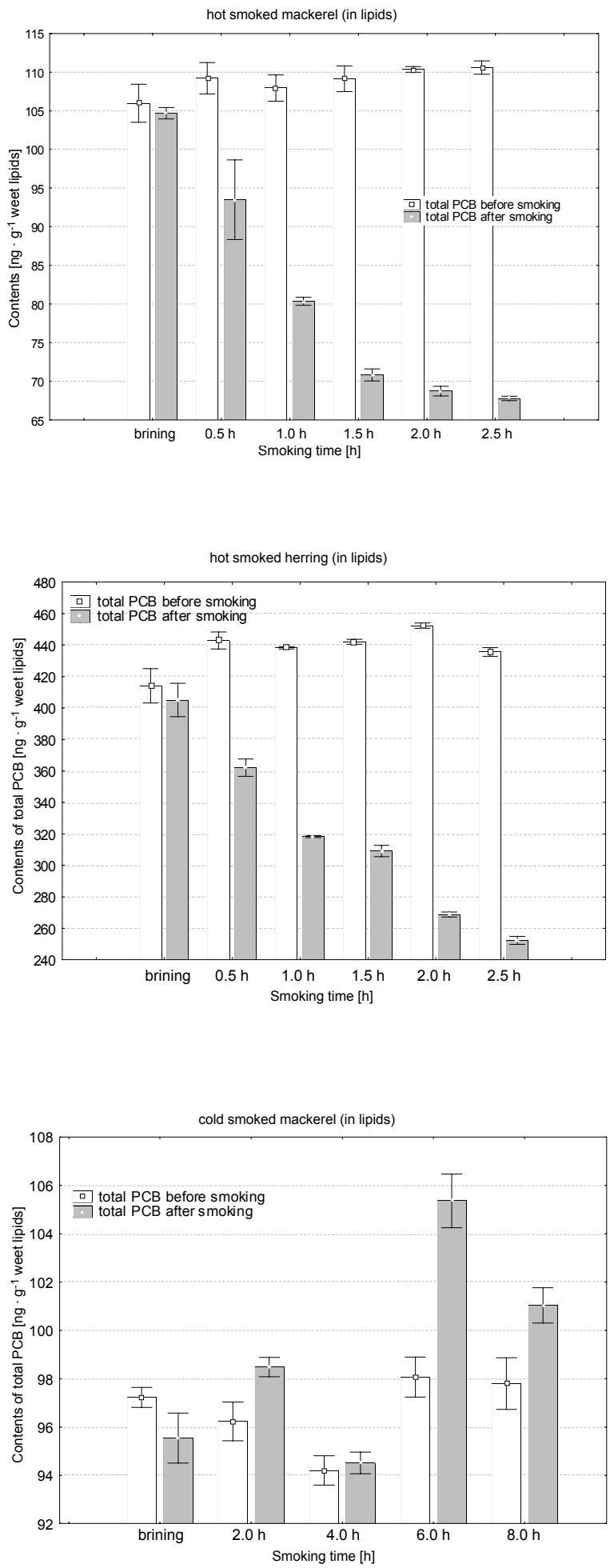

Fig. 1. Total PCB $( \pm s)$ content in the muscle tissue of hot smoked mackerel (a), hot smoked herring (b), and cold smoked mackerel (c) 

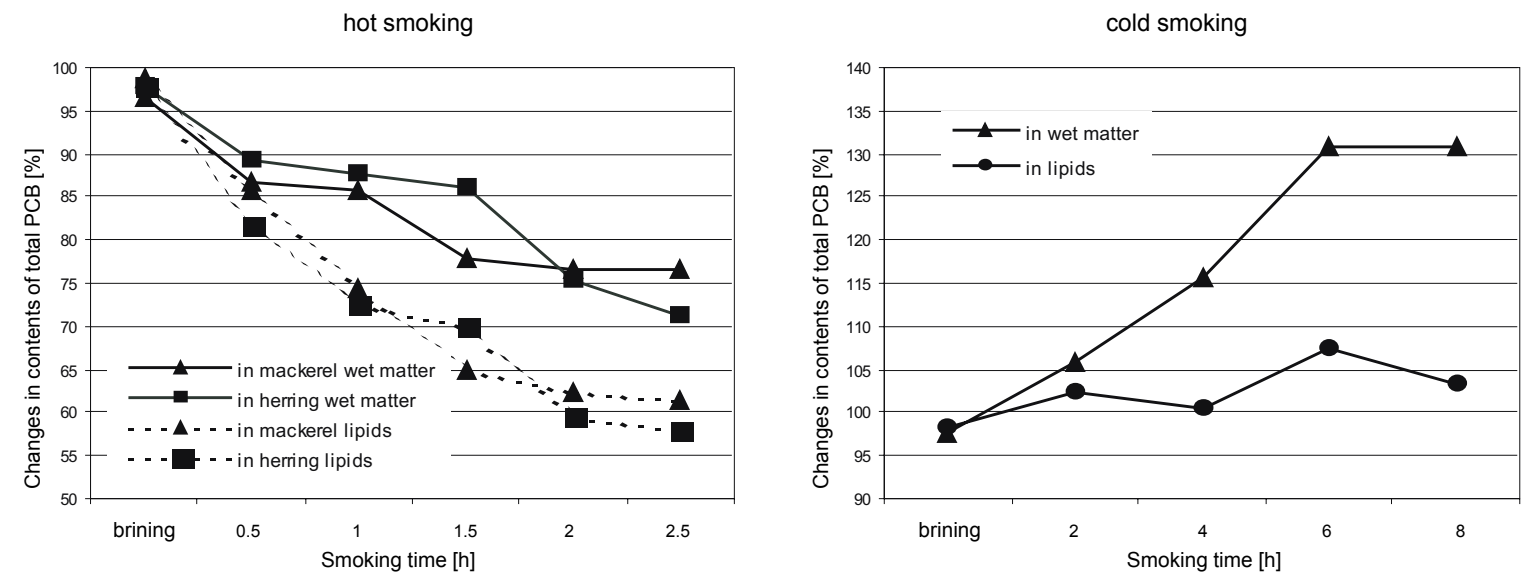

Fig. 2. Percent changes in total $\mathrm{PCB}$ content in the muscle tissue of hot and cold smoked mackerel and herring fillets

to 23.32 percentage points in the final product. In lipids the losses ranged from 25.57 percentage points after $0.5 \mathrm{~h}$ of preliminary drying to 38.71 percentage points after 2.5 $\mathrm{h}$ in the final product (Fig. 2). These changes were statistically significant $(P<0.05)$ in all examined time intervals. At the same time, an increase of dry weight and lipids was observed in the final product, by an average of 14.65 and 25.12 percentage points, respectively.

The hot smoking of herring fillets significantly decreased total PCB content by 13.32 percentage points after $0.5 \mathrm{~h}$ of preliminary drying, and by 30.17 percentage points in the final product after $2.5 \mathrm{~h}$ of smoking (Fig. 2). The content of lipids in the final product increased by 20.54 percentage points in relation to the initial content, with simultaneous increase of dry weight content by 15.87 percentage points, on the average.

During the cold smoking of mackerel fillets, significant increases in total PCB content, compared to initial levels, were observed up to $6 \mathrm{~h}$ (by 30.78 percentage points). However, after lipid normalization, these increases were much lower and statistically non-significant $(P<$
0.05) (Figs. 1, 2). At the same time, as the smoking time was prolonged, a repeated increase in lipid content in the final product (by 26.65 percentage points) was observed compared to the value after $2 \mathrm{~h}$ (by 3.35 percentage points) (Fig. 2), with simultaneous increase of dry matter in the final product by 44.78 percentage points.

While analysing individual factors affecting the changes of PCBs contents in the examined smoked fish flaps, a possible effect of the sawdust and the smoke obtained was taken into account. Sinkkonen et al. (1996) revealed the presence of PCB compounds in pine needles while Ciereszko et al. (2004) detected them in pine bark. However the alder sawdust universally used in smoke-curing has not been analysed considering the contents of PCB compounds.

The total PCB content in alder sawdust amounted to $11.97 \pm 2.79 \mu \mathrm{g} \cdot \mathrm{kg}^{-1}$ dry matter. The smoke obtained from the alder sawdust during destructive wood distillation was $10.82 \pm 3.54 \mu \mathrm{g} \cdot \mathrm{kg}^{-1}$ dry matter of sawdust. The total PCB content in soybean oil on absorbent paper strips, which were hung above with the fish charge in the smok-

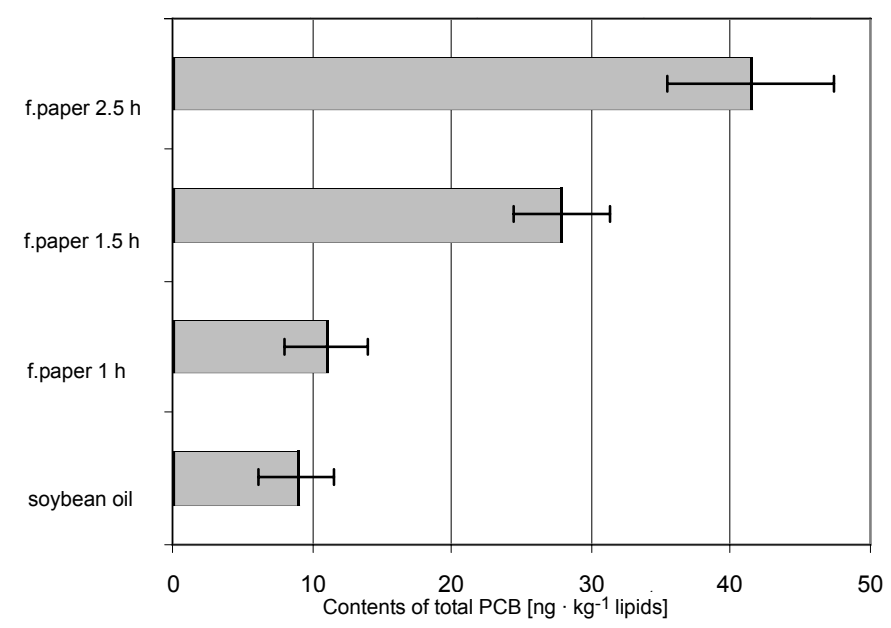

Fig. 3. Changes in total PCB level $( \pm s)$ on filtration paper strips coated with soybean oil during the hot smoking of mackerel fillets 
ing chamber during hot smoking, increased in respective time intervals (Fig. 3). This experiment was provided in order to explain the changes of PCBs contents. These compounds were delivered with smoke to the oil on the filtration paper stripes thus to the fish flaps.

\section{DISCUSSION}

During the hot smoking process, more extensive losses in total PCB were observed in herring fillets when compared to the mackerel fillets (Figs. 1a-b, 2). This result is most likely from difference in the structure and consistency of the muscle tissue of these fish species. Both for the hot smoked mackerel and the herring fillets, negative coefficients of correlation between changes in total PCB content and smoking time $(r=-0.824 \div 0.979 ; P<0.05)$ were obtained in wet weight and when converted into lipids.

The decrease in total PCB content in wet weight and when lipid normalized during the hot smoking process may be explained by the loss of these compounds in codistillation with water vapour, which is suggested by negative rectilinear correlations between water loss and total PCB content change, both for the mackerel $(r=-0.928$; regression line: $y=-10.216-2.236 x)$ and the herring fillets $(r=-0.931 ; y=-4.660-1.393 x)$.

According to Sherer and Price (1993), the temperature of heat processing is a significant determinate of the volatilization rate for these compounds, while their thermal degradation occurs at over $300^{\circ} \mathrm{C}$ (Morita et al. 1978). Zabik et al. (1996), Salama et al. (1998), and Ciereszko and Witczak (2003) also came to similar conclusions, when examining the heat processing methods used commonly for the fillets of different fish species. This may be also observed by the increase of total PCB content in soybean oil on filtration paper strips during the first hour of preliminary drying (Fig. 3).

The repeated increase in the content of these compounds in the hot smoked mackerel fillets results from the presence of PCB in the curing smoke, which penetrated into the smoked fish tissue (Fig. 4). This increase in the final product may be estimated at approximately 15 percentage points.

Based on these studies, total PCB levels in the hot smoked mackerel and herring fillets are a function of changes in the concentration of these compounds in lipids and changes of the percent content of lipids in wet matter of fish tissue during the whole smoking cycle. During the hot smoking of mackerel and herring fillets, strong negative correlations were found between total PCB changes and lipid contents $\left(r_{\text {mackerel }}=-0.98\right.$ and $\left.r_{\text {herring }}=-0.85\right)$. This suggests that such a significant loss of these compounds in lipids, despite the increase of PCBs on a per weight basis in the final product, determined conclusively the decrease of total PCBs. This finding is supported by the earlier studies of Sherer and Price (1993), who determined that PCB losses depended mainly on changes in lipid content, heat processing temperature and duration.

During the whole hot smoking process, dry matter content increased in the final products by 14.65 percentage points in mackerel fillets and by 16.67 percentage points in herring fillets on the average, whereas total PCB content decreased compared to the initial content by 23.32 and 30.17 percentage points, respectively. These results are similar to those obtained earlier by Zabik et al. (1996). They found that out of the heat processing methods examined, the most extensive loss of total PCB concentration (up to $39 \%$ of the final product), in the muscle tissue of lake trout occurred during hot smoking. Salama et al. (1998) concluded that the hot smoking process resulted in the highest decrease in total PCB content (65 percentage points) in the fillets of North Atlantic bluefish, Pomatomus saltatrix, compared to other methods such as baking or pan frying (27-39 percentage point losses).

When examining the cold smoked mackerel fillets, a 30 percentage point increase of total PCB content in the

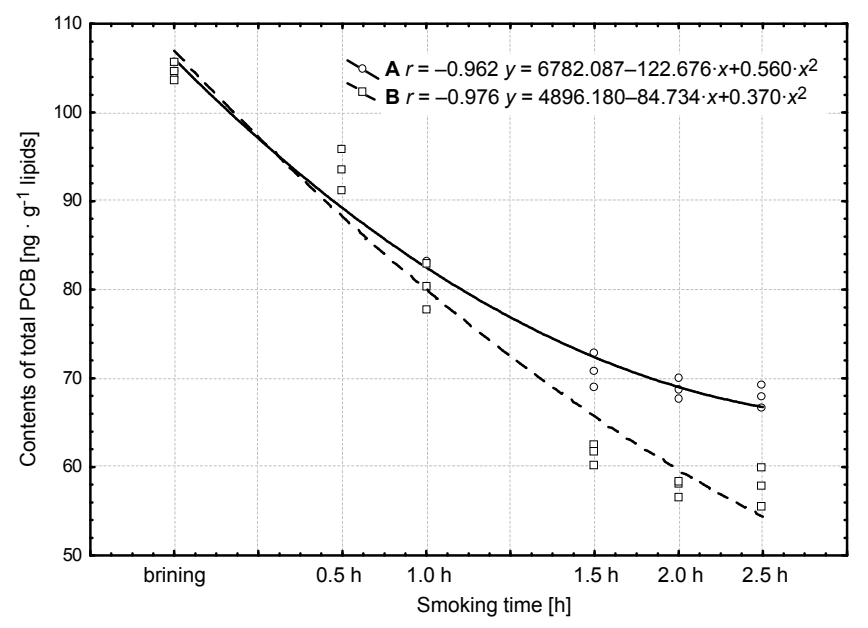

Fig. 4. The impact of curing smoke on changes in total PCB content in the lipids of hot smoked mackerel fillets; (A), total PCB loss curve; (B), hypothetic total PCB loss curve, after subtracting PCB content on filtration paper strips 
final product was observed (Fig. 2). Statistical analysis of the obtained results showed a rectilinear correlation between the increase of total PCB content in the muscle tissue and the length of smoking time $(P<0.05, r=0.936)$. The increase of total PCB content in the wet matter of final product may be explained by lower losses of these compounds in co-distillation with water vapour due to low temperature of cold smoking $\left(25-27^{\circ} \mathrm{C}\right)$, and thereby much compact structure of muscle tissue when compared to the hot smoked fish and penetration of these compounds to the fillets from the curing smoke.

\section{CONCLUSIONS}

1. The hot smoking process resulted in decrease of total PCB content in the examined fish fillets, primarily from the loss of lipid contents.

2. The main factor determining the changes in the level of total PCB content in wet matter and lipids was their loss in co-distillation with water vapour.

3. The increased levels of PCBs in the final stage of hot smoking were most likely the result of contamination from curing smoke.

4. The cold smoking process of mackerel fillets contributed to an increase of PCB content in the final product.

\section{REFERENCES}

Anonymous 1999. Public health implications of exposure to polychlorinated biphenyls (PCBs). U.S. Public Health Service; the Agency for Toxic Substances and Diseases Registry; U.S. Department of Health and Human Services; and the U.S. Environmental Protection Agency.

Booker S.M. 2001. Pulling the plug on POPs. Environmental Health Perspectives 109 (1): A17.

Ciereszko W., Witczak A. 2003. Zmiany w zawartościach wybranych kongenerów PCB w mięsie karpia w wyniku obróbki cieplnej. [Changes in contents of selected PCB congeners in carp meat as a results of thermal processing.] Acta Scientiarum Polonorum. Technologia Alimentaria 2 (1): 155-164. [In Polish.]

Ciereszko W., Witczak A., Tomza A., Borowicz J. 2004. Zawartości ogólnego PCB i kongenerów wskaźnikowych w korze sosny (Pinus sylvestris L.) oraz w glebie na obszarze Leśnictwa Moracz. [The contents of total PCB and its indicative congeners in the pine bark (Pinus silvestris L.) and in the soil within the Moracz Forest Disttrict. Acta Scientarum Polonorum. Silvarum Colendarum Ratio et Industria Lignaria 3 (2): 23-31. [In Polish.]
Falandysz J. 1986. Wyniki oznaczeń poziomu pozostałości polichlorowanych dwufenyli w częściach jadalnych ryb z południowego Bałtyku i w przetworach rybnych. [Determination results of residues of polychlorinated biphenyls in edible tissues of fish from the southern Baltic Sea and in fish products.] Roczniki Państwowego Zakładu Higieny 37 (1): 8-16. [In Polish.]

Falandysz J., Wyrzykowska B., Puzyn T., Strandberg L., Rappe C. 2002. Polychlorinated biphenyls (PCBs) and their congener-specific accumulation in edible fish from the Gulf of Gdańsk, Baltic Sea. Food Additives and Contaminants 19 (8): 779-795.

Hansen L. 1987. Environmental toxicology of polychlorinated biphenyls. Pp.15-48. In: Safe S., Hutzinger O. (eds.). Polychlorinated biphenyls (PCBs): Mammalian and environmental toxicology. Environmental Toxin Series 1. SpringerVerlag, Berlin Heidelberg.

Kurko W.I. 1963. Chemiczne i fizykochemiczne podstawy procesu wędzenia. [The chemical and physico-chemical foundations of smoking process.] Wydawnictwo Przemysłu Lekkiego i Spożywczego, Warszawa. [In Polish.]

Morita M., Nagakawa J., Rappe C. 1978. Polychlorinated dibenzofuran (PCDF) formation from PCB mixture by heat and oxygen. Bulletin of Environmental Contamination and Toxicology 19: 665-670.

Salama A.A., Mohamed M.A.M., Duval B., Potter T.L., Levin R.E. 1998. Polychlorinated biphenyl concentration in raw and cooked North Atlantic bluefish (Pomatomus saltatrix) fillets. Journal of Agricultural and Food Chemistry 46: 1359 1362.

Sherer R.A., Price P.S., 1993. The effect of cooking processes on PCB levels in edible fish tissue. Quality Assurance, San Diego 2: 396-407.

Sinkkonen S., Welling L., Vattulainen A., Lahti L., Lahtipera M., Paasivirta J. 1996. Short chain aliphatic halocarbons and polychlorinated biphenyls in pine needles: effects of metal scrap plant emissions. Chemosphere 32 (10): 19711982.

Zabik M.E., Booren A., Zabik M.J., Welch R., Humphrey H. 1996. Pesticide residues, PCBs and PAHs in baked, charbroiled, salt boiled and smoked Great Lakes lake trout. Food Chemistry 55 (3): 231-239.
Received: 23 October 2005 Accepted: 18 February 2006 